\title{
RARE RECORDS OF THE FALSE KILLER WHALES (PSEUDORCA CRASSIDENS) IN THE ADRIATIC SEA
}

\author{
DrašKo Holcer ${ }^{1,2}$, Jure Miočić-Stošić ${ }^{1,2} \&$ Tihana Vučur Blazinić ${ }^{2}$ \\ ${ }^{1}$ Croatian Natural History Museum, Demetrova 1, 10000 Zagreb, Croatia \\ (E-mail: Drasko.Holcer@hpm.hr; Jure.MiocicStosic@hpm.hr)
}

${ }^{2}$ Blue World Institute of Marine Research and Conservation, Kaštel 24, 51551 Veli Lošinj, Croatia

(E-mail: tihana.vucur@blue-world.org)

Holcer, D., Miočić-Stošić, J. \& Vučur Blazinić, T.: Rare records of the false killer whales (Pseudorca crassidens) in the Adriatic Sea. Nat. Croat., Vol. 30, No. 1, 263-268, Zagreb, 2021.

In spring 2021, four unusual encounters with a group of false killer whales were recorded in Kvarner Bay, Northern Adriatic Sea. A minimum of five individuals, including a calf, were observed and two photos were taken corroborating species identification. These are the first reported sightings of the species in the Adriatic Sea since the mid-twentieth century. In addition, another encounter was revealed that occurred at the end of the 2000s in the same location and should be added to the list of historic observations. These reports were obtained by chance and show the importance of citizen science in obtaining data on rare marine species. The information gathered goes towards a better understanding of the distribution of the species in the Mediterranean Sea.

Keywords: Mediterranean Sea, Cetacea, distribution, citizen science

Holcer, D., Miočić-Stošić, J. \& Vučur Blazinić, T.: Rijetki nalazi crnog dupina (Pseudorca crassidens) u Jadranskom moru. Nat. Croat., Vol. 30, No. 1, 263-268, Zagreb, 2021.

Četiri rijetka opažanja crnih dupina zabilježena su u proljeće 2021. u Kvarnerskom zaljevu, u sjevernom Jadranskom moru. Opaženo je najmanje pet jedinki, uključujući i jednog mladunca, a načinjene su i dvije fotografije koje potvrđuju identifikaciju vrste. Ovo su prva opažanja crnih dupina u Jadranskom moru od sredine dvadesetog stoljeća. Osim toga, otkriveno je još jedno opažanje koje se dogodilo krajem 2000-tih na istoj lokaciji, a koje je potrebno dodati povijesnim podacima o opažanjima vrste na ovom području. Informacije su prikupljene oportunistički i naglašavaju važnost građanske znanosti u prikupljanju podataka o rijetkim morskim vrstama, a poslužit će boljem razumijevanju rasprostranjenosti ove vrste u Sredozemnom moru.

Ključne riječi: Sredozemno more, Cetacea, rasprostranjenost, građanska znanost

False killer whales, Pseudorca crassidens (Owen, 1846) are large delphinids with males reaching almost $6 \mathrm{~m}$ in length, and females growing up to about $5 \mathrm{~m}$ (STACEY et al., 1994). Their body is almost black, and some contrasting coloration may be present in the form of light, grey patches on the sides of the head and a light grey to whitish line on the ventral side. They are widely distributed from tropical to temperate oceanic waters (Odell \& McClune, 1999) and considered to be an oceanic species that occasionally nears oceanic islands (BAIRD, 2018) or the continental shelf and coast (PAlmer et al., 2009; Weir et al., 2013). It is a gregarious species and pods may include over 100 animals (STACEY et al., 1994). They feed on large fish species and cephalopods (Stacey et al., 1994; Koen Alonso et al., 1999) leading to occasional negative interaction with fisheries. Due to depredation on hooked fish and bait, some individuals are occasionally bycaught or taken intentionally (BAIRD, 2008). 
This species is neither abundant nor easily accessible for study and our knowledge on its ecological traits, population size, migration patterns and other aspects of its biology is limited. Indications of threats like bycatch, prey depletion and anthropogenic noise, coupled with an observed population decline has resulted in a Near Threatened IUCN global species conservation status (BAIRD, 2018).

False killer whales occasionally stray into the Mediterranean Sea and are considered visitors. In the Mediterranean, more than 50 different sighting and stranding occasions have been recorded since the $18^{\text {th }}$ century (Notarbartolo Di Sciara, 2016; Calogero et al., 2021). A disproportionately high number of observations have been recorded in the past few years. In the Eastern Mediterranean there has been a series of sightings: along the Israeli coast in the period May-July 2020 and off the coast of Lebanon on 12 May 2020 (Kerem et al., 2020) as well as in several other locations in the Levantine basin (Kerem et al., 2012; RYAn et al., 2014; BAŞ et al., 2017; ACCOBAMS, 2021). The most recent sightings include a group of eight false killer whales filmed in the northern Aegean Sea off Gökçeada Island, Turkey in January 2020 (DEDE et al., 2020) and a group observed in the Ionian Sea, near Port Germeno, Corinthian Gulf, Greece in June 2021 (ARION, 2021). In the western Mediterranean, several observations were reported in the period 2019-2020 along the west coast of Italy, in the Tyrrhenian and Ligurian seas (CALOGERo et al., 2021). This includes the sightings of larger groups of 30-40 animals that occurred in April 2019 off the coast of Amalfi, Italy (MAio et al., 2019) and, most recently, off Savona, Italy in September 2020 (CALOGERO et al., 2021).

Historically, only two sightings in the Adriatic Sea have been recorded (Fig. 1). An individual was caught near the city of Korčula (Korčula Island, Croatia) on $21^{\text {st }}$ October 1936 (Hirtz, 1938). It measured only $1.8 \mathrm{~m}$ in length, indicating it was a juvenile animal. Contrary to expectations, this record does not mention any observations of any group of animals of which this individual was a part but includes a statement that the animal was "jumping some 10 meters from the shore" before it was caught. Another three individuals from a pod of 30-40 false killer whales were reportedly captured in waters off Ravenna, Italy, in a fishing episode that occurred between 1959 and 1961 (Stanzani \& Piermarocchi, 1992). Here we report an observation of a group of false killer whales observed on several occasions in the Kvarner Bay, Northern Adriatic, in spring 2021.

In the period from April to May 2021, a group of false killer whales was observed on four occasions in the vicinity of the Adriatic Gate Container Terminal in Rijeka, Croatia (Fig. 1) by a professional diver regularly working on site. The diver initially reported an observation of "large, dark coloured dolphins with no rostrum and similar to beluga" upon which the authors assumed these could be pilot whales (Globicephala sp.) and on $5^{\text {th }}$ May made a public call for additional info through social media which, to date, has not resulted in reports of other observations. However, on $21^{\text {st }}$ May, the same person observed the group for the third time and managed to take two photos that show false killer whales swimming in a tight group. Species identification was based on head shape, the relative size and shape of the dorsal fin, body colouration (Fig. 2), and body length estimates, following (Oleson et al., 2010).

The group was seen heading in a south-easterly direction at an estimated speed of $10 \mathrm{kts}$ and at a distance of around $300 \mathrm{~m}$ from the shore. The observer reported 4-5 animals in the group, including several calves. The first image shows two animals 


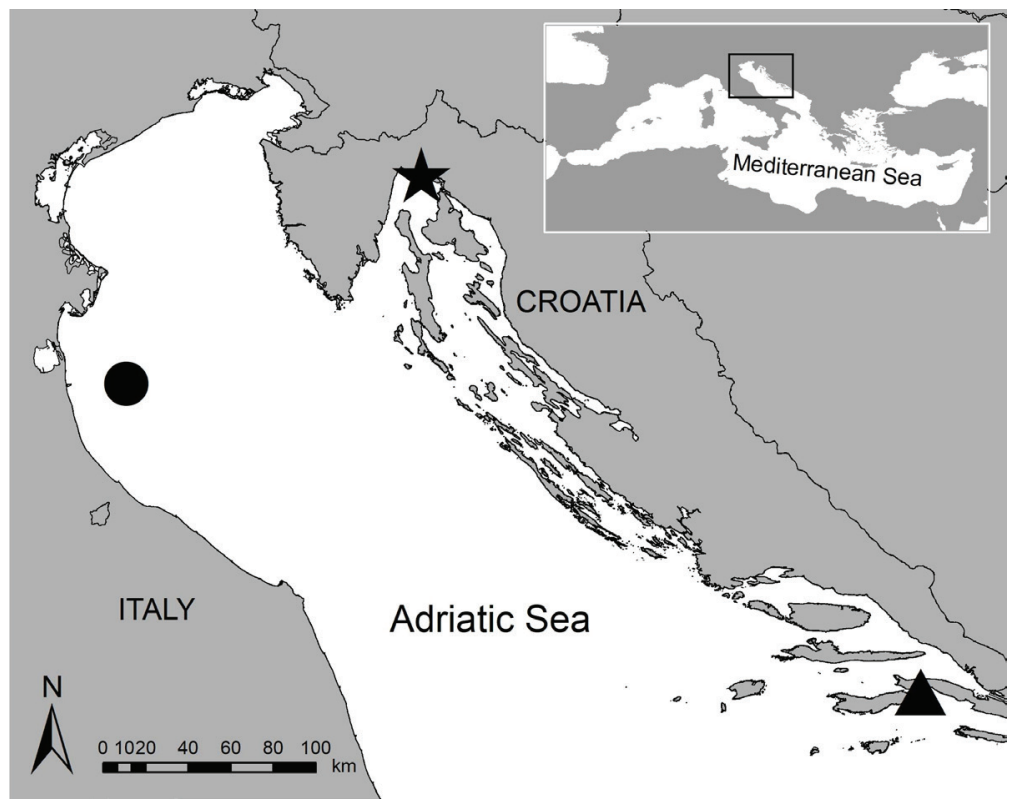

Fig. 1. Locations of observations of false killer whales in the Adriatic: off Ravenna in 1959-1961 (STANzani \& Piermarocchi, 1992) (black circle); near Korčula in 1936 (Hirtz, 1938) (black triangle); this study (black star).

(Fig. 2A) and a minimum of five individuals can be discerned in the second image, as outlined in Fig. 2C. We could not identify whether any individuals are represented in both photographs. Therefore, based on photographs alone, the group may have comprised a maximum of seven individuals. However, since only two images are available, it is possible some animals may not have been photographed at all. At least one calf was present in the images. The group was since observed once more in the same location, around a week later (end of May 2021) but there is no media documentation of the sighting.

Dorsal fins of two individuals were completely visible (Fig. 2A) with enough detail for photoidentification and matching with existing or future observations. One shows a partially submerged dorsal fin, and only the head or the posterior body parts of the remaining individuals can be viewed in the images (Fig. 2B). Due to low quality of both the images presented here and the video of a recent sighting in Turkey (DEDE et al., 2020) we could not confirm a positive match between any animals present in the two groups. In addition, we have shared the images with three other research organisations having access to photographs of false killer whales recently observed in the Mediterranean (Menkab Italy, Oceano Mare Delphis Italy, Morris Kahn Marine Research Station Israel) but no match could be made.

Interestingly, the observer recounted another sighting of a small group about ten years preivously that he is positive was the same species, but no pictures or video were taken that could be used to confirm species identification. At the time, these animals were also present in the same area for several days, as he recalls seeing them on a few occasions. Considering the reliability of his information and his initial detailed description of these animals before any photographs were taken and his 

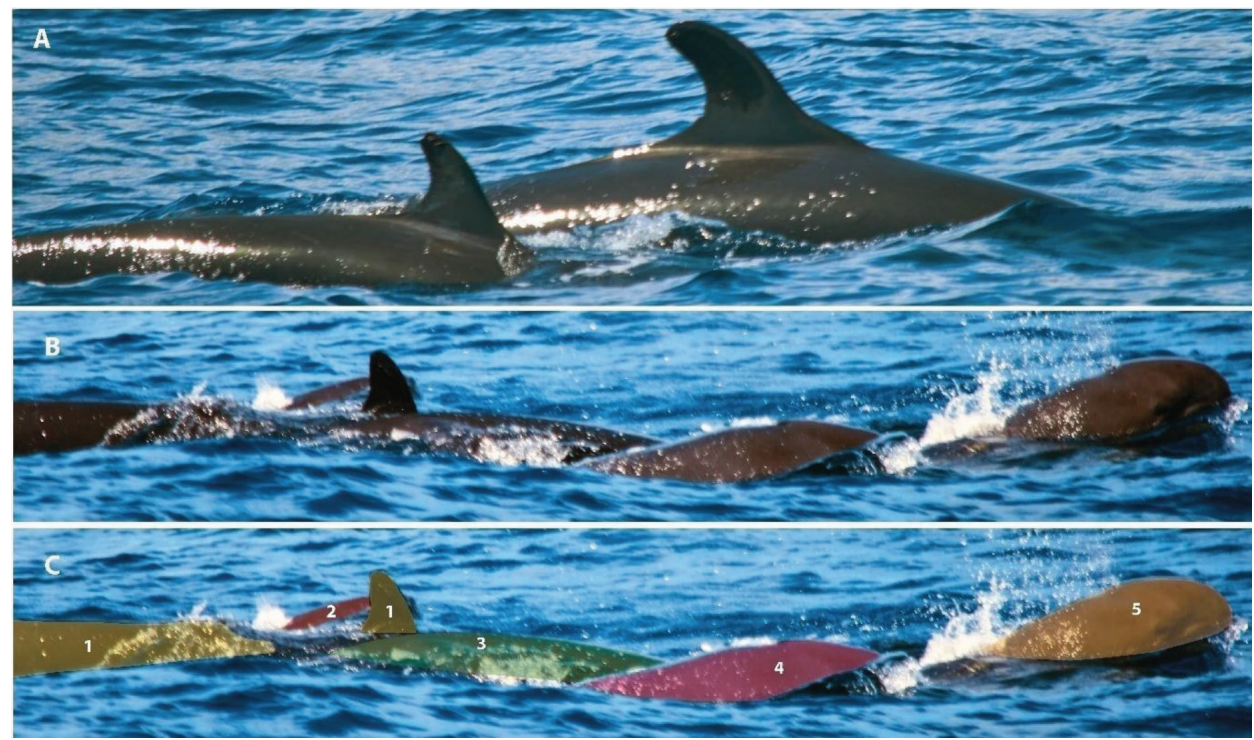

Fig. 2. A -Image showing the dorsal fins of two individuals in the group; B - Image with most individuals of false killer whales visible at the same time; C -Copy of image A with five individuals highlighted by different colours and numbered 1-5; (Author: R. Puž, original images cropped).

interest in marine fauna, we believe this data is valid and should be added to the list of recorded occurrences of the species in the Adriatic Sea.

The presence of at least one calf in this group, in addition to juveniles present in groups observed in the Aegean (DEDE et al., 2020), Tyrrhenian (MAIO et al., 2019), Ligurian (CALOGERo et al., 2021), and a newborn stranded on the Israeli coast (Kerem et al., 2020), further supports previous assumptions of a possible resident population reproducing in the eastern Mediterranean possibly expanding its range. However, its range, abundance and demographic parameters remain largely unknown and should be the focus of dedicated studies in the future. Collaboration between research groups and data sharing is of particular importance for establishing possible connections between these observations and full-size images of this sighting are available for photoidentification purposes.

The apparent scarcity of data regarding this species on a global scale adds value to any observations and pertaining information that can be used to understand species distribution. A relatively high number of sightings throughout the eastern-central Mediterranean in the last 20 years supports the presumption of the existence of a resident population reproducing in the eastern Mediterranean as suggested by NoTARBARTOLO DI SCIARA (2016). The increased availability of mobile cameras and ease of sharing information through social networks and the Internet seems responsible for this increase in reporting information that would otherwise go unnoticed. Citizen science programmes have been used to engage people in data collection on both terrestrial and marine realms (GARCIA-SOTO et al., 2021). In that sense, promoting citizen science (public participation in scientific research) and creating easy means of sharing observations with scientists is becoming an obvious way forward. Citizen science 
programmes may have value when the collection of information on rare species, species with low abundance and invasive and alien species is being considered (HOLCER \& LAZAR, 2017; Tiralongo et al., 2020; ENCARNAÇÃo et al., 2021). As a proven concept in biodiversity studies and nature conservation, citizen science also mitigates the lack of funding needed for field research, particularly when standard sampling procedures are too expensive to detect low-abundance species (LeE et al., 2020; LeHTINIEMi et al., 2020). Therefore, organising citizen science campaigns and programmes that invite the public to share information that may seem perhaps irrelevant or without value may have a major impact by providing additional information on the distribution and abundance of species in many areas where they are not considered resident. Such a conclusion is supported by the fact that the observer providing information presented here did not consider his sightings worth sharing, mostly because he "did not consider these dolphins (false killer whales) so rare". However, after learning that there is an interest and value to his observations, he recalled and disclosed numerous other accounts of his observations related to some large marine vertebrates made throughout his professional career spent at sea as technical diver.

Events like these, where the presence of a previously considered rare species is unexpectedly increasing, may support the hypothesis that recent environmental changes, particularly global warming, might contribute to increasing the suitability of Mediterranean and Adriatic Sea habitats and result in (re-)expanding their original range.

\section{ACKNOWLEDGMENTS}

We are grateful to Mr. Roberto Puž for providing the images and information related to the observations. We are thankful to Dr Biagio Violi - Menkab: il respiro del mare, Savona, Italy, Barbara Mussi - Oceano Mare Delphis, Ischia, Italy, and Dr Aviad Sheinin - Morris Kahn Marine Research Station, University of Haifa, Israel for providing further information from their respective databases.

Received June 1, 2021

\section{REFERENCES}

ACCOBAMS, 2021: Estimates of abundance and distribution of cetaceans, marine mega-fauna and marine litter in the Mediterranean Sea from 2018-2019 surveys. In: ACCOBAMS Survey Initiative Project (Eds. Panigada S., Boisseau O., Canadas A., Lambert C., Laran S., Mclanaghan R. \& Moscrop A.), p. 177, Monaco.

ARION, 2021: Rare sighting of a False killer whale (Pseudorca crassidens). URL https://www.facebook.com/257780104308605/posts/4201746216578621/

Baird, R., 2008: False Killer Whale: Pseudorca crassidens. In: Encyclopedia of Marine Mammals (Eds. Wursig B., Perrin W.F. \& Thewissen J.G.M.), pp. 411-2. Academic Press.

BAIRD, R., 2018: Pseudorca crassidens (errata version published in 2019). The IUCN Red List of Threatened Species 2018: e. T18596A145357488. https://dx.doi.org/10.2305/IUCN.UK.2018-2.RLTS. T18596A145357488.en

Baş, A.A., Erdoğan, M.A., Ulusoy, E., Aslan, B.E., Kurt, M., Port, J., Melis Basmaci, M. \& Baş, E., 2017: Marine mammals of the North Levantine Sea - Annual Report 2016-2017. p. 26. Marine Mammals Research Association.

Calogero, G., Biasissi E., Bottaro M., Capone A. \& Violi B., 2021: Occurrence of false killer whales Pseudorca crassidens pod in the Ligurian Sea and review of Mediterranean records. Hystrix. https:/ / doi.org/10.4404/hystrix-00428-2021 
Dede, A., Tonay, A.M., GönÜlal O. \& ÖZtürk, A.A., 2020: First sighting of false killer whales (Pseudorca crassidens) in the northern Aegean Sea. J Black Sea Mediterr Environ 26, 106-11.

Encarnação, J., Teodósio M.A. \& Morais, P., 2021: Citizen Science and Biological Invasions: A Review. Frontiers in Environmental Science 8(303). https:/ / doi.org/10.3389/fenvs.2020.602980

Garcia-Soto, C., Seys, J.J.C., Zielinski O., Busch J.A., Luna S.I., Baez J.C., Domegan C., Dubsky K., Kotynska-Zielinska I., Loubat P., Malfatti F., Mannaerts G., McHugh P., Monestiez P., van der Meeren G.I. \& Gorsky, G., 2021: Marine Citizen Science: Current State in Europe and New Technological Developments. Frontiers in Marine Science 8(241). https://doi.org/10.3389/ fmars.2021.621472

Hirtz, M., 1938: Rijetke vrste delfina u vodama Korčule. Priroda 27(1), 25-8.

Holcer, D. \& Lazar, B., 2017: New data on the occurrence of the critically endangered common angelshark, Squatina squatina, in the Croatian Adriatic Sea. Natura Croatica 26(2), 313-20. https:/ / doi.org/10.20302/NC.2017.26.23

Kerem, D., Gali, O. \& Goffman, O., 2020: News from IMMRAC 2020. In: Fins - Newsletter of ACCOBAMS. ACCOBAMS, Monaco.

Kerem, D., Hadar, N., Goffman O., Scheinin, A., Kent R., Boisseau O. \& Schattner, U., 2012: Update on the Cetacean fauna of the Mediterranean Levantine basin. Open Marine Biology Journal 6, 6-27.

Koen Alonso, M., Pedraza, S.N., Schiavini A.C., Goodall R.N.P. \& Crespo, E.A., 1999: Stomach contents of false killer whales (Pseudorca crassidens) stranded on the coasts of the Strait of Magellan, Tierra del Fuego. Mar. Mamm. Sci. 15(3), 712-24. https://doi.org/10.1111/j.1748-7692.1999. tb00838.x

Lee, K.A., Lee J.R. \& Bell, P., 2020: A review of Citizen Science within the Earth Sciences: potential benefits and obstacles. Proceedings of the Geologists' Association 131(6), 605-17. http://doi. org/10.1016/j.pgeola.2020.07.010

Lehtiniemi, M., Outinen, O. \& Puntila-Dodd, R., 2020: Citizen science provides added value in the monitoring for coastal non-indigenous species. J Environ Manage 267, 110608. https://doi. org /10.1016/j.jenvman.2020.110608

Maio, N., Petraccioli, A., De Stasio R., Loreto A., Viglietti S., De Maio L. \& Pollaro, F., 2019: Anche la cetofauna sta cambiando: avvistamenti di specie di Cetacei rare o mai osservate prima nei mari della Campania (Mar Tirreno). Quaderni del Museo Civico di Storia Naturale di Ferrara 7, 81-90.

Notarbartolo di Sciara, G., 2016: Marine mammals in the Mediterranean Sea: An overview. In: Advances in marine biology (Eds. Notarbartolo di Sciara G., Podestà M. \& Curry B.E.), pp. 1-36. Elsevier, London, UK. https:/ / doi.org/10.1016/bs.amb.2016.08.005

Odell, D.K. \& McClune, K.M., 1999: False killer whale Pseudorca crassidens (Owen, 1846). In: Handbook of marine mammals (Ed. Ridgway S.), pp. 213-43. Academic Press, New York.

Oleson, E.M., Boggs, C.H., Forney, K.A., Hanson M.B., Kobayashi D.R., Taylor B.L., Wade, P.R. \& Ylitalo, G.M., 2010: Status review of Hawaiian insular false Killer whales (Pseudorca crassidens) under the Endangered Species Act.

Palmer, C., Fitzgerald P., Wood A., Harley, S. \& McKenzie, A., 2009: False Killer Whales Pseudorca crassidens: Regular Visitors to Port Essington and Darwin Harbour in the Northern Territory, Australia. Northern Territory Naturalist 21, 49-53.

Ryan, C., Cucknell, A.C., Romagosa M., Boisseau O., Moscrop A., Frantzis, A. \& Mclanaghan, R., 2014: A visual and acoustic survey for marine mammals in the eastern Mediterranean Sea during summer 2013. p. 55. Marine Conservation Research International, Kelvedon, UK, International fund for animal welfare.

Stacey, P.J., Leatherwood, S. \& Baird, R.W., 1994: Pseudorca crassidens. Mammalian Species (456), 1-6.

Stanzani, L. \& Piermarocchi, C., 1992: Cattura di alcuni individui di Pseudorca crassidens (Owen, 1846) in Adriatico. Atti Soc. Ital. Sci. Nat. Mus. Civ. St. Nat. Milano 133, 85-95.

Tiralongo, F., Crocetta F., Riginella E., Lillo A.O., Tondo, E., Macali A., Mancini E., Russo, F., Coco, S., Paolillo, G. \& Azzurro, E., 2020: Snapshot of rare, exotic and overlooked fish species in the Italian seas: A citizen science survey. J Sea Res 164, 101930. https://doi.org/10.1016/j. seares.2020.101930

Weir, C., Collins T., Cross T., Gill A., Elwen, S., Unwin, M. \& Parnell R., 2013: False killer whale (Pseudorca crassidens) in continental shelf habitat off Gabon and Côte d'Ivoire (Africa). Marine Biodiversity Records 6, e65. https:/ / doi.org/10.1017/S1755267213000389 